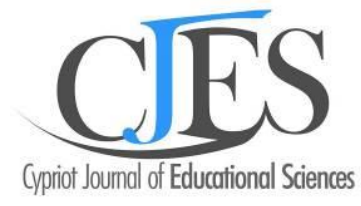

$\underline{\text { www.cjes.eu }}$

\title{
Reviewing the life skills activity program for children with special needs during the COVID-19 pandemic
}

\author{
Diana Diana * Sebelas Maret University, Indonesia \& Lecture in Early Childhood Teacher Education Department, \\ Universitas Negeri Semarang, Indonesia
}

Sunardi Sunardi ${ }^{b}$, Sebelas Maret University, Doctoral Program in Faculty of Education, Indonesia

Gunarhadi Gunarhadi c, Sebelas Maret University, Doctoral Program in Faculty of Education, Indonesia

Munawir Yusufi ${ }^{d}$, Sebelas Maret University, Doctoral Program in Faculty of Education, Indonesia

\section{Suggested Citation:}

Diana, D., Sunardi, S., Gunarhadi, G \& Yusufi, M. (2021). Reviewing the life skills activity program for children with special needs during the COVID-19 pandemic. Cypriot Journal of Educational Science. 16(6), 3240-3254. https://doi.org/10.18844/cjes.v16i6.6543

Received from August 30, 2021; revised from October 30, 2021; accepted from December 09, 2021.

(C)2021 Birlesik Dunya Yenilik Arastirma ve Yayincilik Merkezi. All rights reserved

\begin{abstract}
The pandemic, which occurs in all parts of the world has changed the order of the learning process for children with special education needs (SEN) which was initially carried out face-to-face to the online distance learning from home. This study aims to see the impact of the Inclusive Teaching (I-Teach) model on the life skills of early childhood students with special needs while studying from home during the covid-19 pandemic. This study is survey research with data analysis using the percentage of life skills assessment in children with special needs, carried out at 6 early childhood education institutions that have children with special needs totaling 12 students with the following specifications: 5 students with autism spectrum disorder, 1 student with speech delay, 2 students with attention deficit hyperactivity disorder, 1 student with down syndrome, and 3 other students who have not been diagnosed.The research found that, from the six aspects of special needs childrens' life skills, most of them can self-feeding. It showed when children used the cutlery to clean the dishes by themselves. Meanwhile, for the dressing skill, personal hygiene, self-awareness, safety, and others, children still need reinforcement from parent and teacher.
\end{abstract}

Keywords: Life Skills, SEN, Early Childhood;

* ADDRESS FOR CORRESPONDENCE: Diana, Diana, Doctoral Program, Sebelas Maret University, \& Lecture in Early Childhood Teacher Education Departemen, Universitas Negeri Semarang, Indonesia

E-mail address: diana@mail.unnes.ac.id / Tel.: +62-857-2689-9420 


\section{Introduction}

The government's policy is for students, especially at the early childhood education level, to study at home during the COVID-19 pandemic. This became a challenge for educators and parents to design the most appropriate strategy. The learning process for early childhood during this pandemic should not be fully cognitive oriented but learning to strengthen life skills through daily activities.

The focused life skills for students with special needs in early childhood education institutions are their ability in four aspects including personal skills and safety, socio-emotional development, language development, as well as cognitive and motor development which aims to make them more accepting toward their peers in class (The University of the State of New York, 2003, p. 8). It is further explained that some of the learning outcomes and indicators for children in special/inclusive in early childhood education are of Personal Health and Safety Skills, including: (1) personal health skills, (2) safety and self-protection, (3) interacting with adults. This shows that early childhood education equips special needs children with various skills and life skills which will later be used to achieve further skills and abilities.

Based on the research that has been carried out by Gatumu \& Kathuri (2018), it describes that the life skills that are taught in the learning process refer to early childhood in the pre-school environment including: (a) Self-feeding, (b) Dressing, (c) Personal hygiene, (d) Self-awareness, where children are expected to be able to understand themselves, able to control emotions and calm themselves when facing undesired circumstances, (e) Safety, where children are expected to have sensitivity and ability to avoid dangers around them, during learning activities or during play activities, and (f) Relating well with others.

It is not an easy task to train life skills for early childhood students with special needs during the distance learning period where the children are fully accompanied only by their parents or family members at home. While at school, teachers have a very big role to be able to practice these skills, and only afterwards are those skills be strengthened and repeated at home with parents. For children with special needs, the role of parents currently has a major role, because children are fully taught and trained by parents while studying at home during the pandemic. However, teachers as educators can also help parents who are still learning and facing difficulties with their children's needs. Parents who have not been equipped with much knowledge in dealing with children with special needs must also be open and ready to receive various information so that the skills needed by children can be implemented with their children at home. Teaching life skills to children at preschool age pave the way for them to fulfill their social and school responsibilities, this means that life skills activities are very important to be taught to children. Padillo $(2021$, p. 1893) in his research describes that the challenges faced by parents while teaching functional skills during the pandemic include the lack of relevance of the training followed by parents, lack of knowledge about parenting and lack of time to provide assistance.

During the COVID-19 pandemic, all activities outside the home, including educational, religious, economic and many other activities were changed by doing them at home or working from home, because during the COVID-19 pandemic, the government carried out and implemented a policy that all activities outside the home are canceled or suspended until the corona virus outbreak ends. The outbreak of covid-19 or the corona virus has changed many activities of a public nature to shift to the main activity centered at home, this affects many fields, including the world of education (Wijoyo, 2020, p. 205). Through this policy and in the current COVID-19 pandemic conditions, educational institutions are demanding new innovations in their learning activities, one of the new forms of innovation is to conduct online learning activities (Jamaluddin: 2020, p. 2). The existence of this COVID-19 pandemic 
requires educational institutions to redesign or change the process of learning activities, which were initially carried out in schools directly or face-to-face, are now carried out at home or online (Wadji, 2020 , p. 269). In fact, in the process of online learning activities, this is the correct or appropriate alternative to provide learning materials to students during the COVID-19 pandemic as it is today (Assingkily, 2020:59). This also has an impact on inclusive early childhood education institutions, by accepting children with special needs in them. They find it difficult to facilitate learning during the pandemic, because children with special needs will find it easier to receive information or skills directly with face-to-face and repeated habits at school.

One of the model developments that have been developed by researchers in previous studies is a model that facilitates children with special needs in inclusive institutions. The model developed by the researcher is the inclusive teaching model called I-Teach, where this model is intended to guide teachers in early childhood education institutions that accept children with special needs (Diana et al, 2020, p. 1617). Diana (2020) in a previous study described that this I-Teach model provides opportunities for children with special needs to be able to optimize their growth and development according to their needs, one of the activities developed is in the form of arrival activities, which are designed to train life skills for the students. Children with special needs and develop other developmental aspects such as language, physical motor, social and emotional skills (p. 1623). The I-teach model offers strategies for teachers who handle inclusive classes to help develop life skills of preschool students while studying from home with parents and family. If children are at home, they are still introduced and trained in their life skills through online meetings accompanied by parents and learning videos that contain steps in implementing children's life skills indicators. This study aims to see the impact of the inclusive teaching (I-Teach) model on the life skills of early childhood children with special needs while studying from home during the COVID-19 pandemic.

\section{Methodology}

\subsection{Research Design}

This research is a quantitative study using a survey, where the method is to collect information from groups that represent a population or a large number of responden. This survey is to determine the implementation of the inclusive teaching (I-Teach) model in the implementation of the life skills program for children with special needs during the COVID-19 pandemic in inclusive schools, especially in early childhood education institutions.

\subsection{Sampel and Data Collection}

This study was carried out in 6 early childhood education institutions that were designated as inclusive pre-schools in Semarang City area with 12 children with special needs who were involved in this study. The participants involved in the research are described in table 1 below.

Table 1. Participants Data Based on Gender

\begin{tabular}{lll}
\hline Gender & Number of Students & Percentage \\
\hline Girl & 3 & $25 \%$ \\
Boy & 9 & $75 \%$ \\
\hline
\end{tabular}

Based on the table above, it can be explained that the participants of this study consisted of 3 girls and 9 boys. The data in this study were collected through observation sheets for children with special needs on aspects of life skills that should be mastered in early childhood. In addition, document in the 
form photos and videos of children's life skills activities are narrated to provide reinforcement on the observation sheet that been given.

\subsection{Instruments}

The instrument used in this study was adapted from the Life Skills instrument that has been developed by Gamutu \& Kathuri (2018) which is intended for preschool age children. The instrument indicators measure the life skills of children with special needs in the form of of feeding self, dressing, personal hygiene, self-awareness, safety, relating well with others which had been adapted to the abilities of children with special needs at an early age. Assessment of the life skills of early childhood children with special needs also had been adapted to the abilities of each child with special needs. The following are the assessment standards for early childhood with the following criteria describe in table 2: (Ministry of Education \& Culture, 2020)

Table 2. Life Skills Achievement Criteria

\begin{tabular}{lc}
\hline \multicolumn{1}{c}{ Criteria } & Score \\
\hline Has not developed & 1 \\
Start developing & 2 \\
Developing as expected & 3 \\
Developing very well & 4 \\
\hline
\end{tabular}

\subsection{Data Analysis}

Quantitative data were analyzed through descriptive statistics using the percentage of assessment of life skills in children with special needs. While supporting data in the form of observations and interviews were also used in this study.

\section{Finding/Result}

This study explores the impact of the inclusive teaching (I-Teach) model implementation carried out by teachers on the life skills of early childhood children with special needs while studying from home during the covid-19 pandemic. The twelve (12) students with special needs who participated in this study are as follows:

Table 3. The Participants' Special Need Specifications

\begin{tabular}{|c|c|c|c|}
\hline \multicolumn{2}{|l|}{ Diagnosis } & $\begin{array}{l}\text { Number } \\
\text { Students }\end{array}$ & Percentage \\
\hline \multicolumn{2}{|l|}{ Autism Spectrum Disorder } & 5 & $42 \%$ \\
\hline \multicolumn{2}{|l|}{ Speech Delay } & 1 & $8 \%$ \\
\hline \multirow{2}{*}{$\begin{array}{l}\text { Attention Deficit } \\
\text { (ADHD) }\end{array}$} & Disorder & 2 & $17 \%$ \\
\hline & & 1 & $8 \%$ \\
\hline \multicolumn{2}{|l|}{ Down Syndrome } & 3 & $25 \%$ \\
\hline \multicolumn{4}{|l|}{ Undiagnosed } \\
\hline
\end{tabular}

Based on the data above, it can be described that the specifications in this study are the highest number of children with autism spectrum disorder specifications, followed by specifications for children with attention deficit hyperactivity disorder (ADHD), while the number of children with speech delay 
and Down syndrome specifications is the same. The rest are children who have not been diagnosed but based on the results of the identification and assessment carried out by the teachers, these children experienced obstacles and disturbances in their growth and development. Referring to the table above which shows that of the total number of children, the number of boys who experience barriers is higher than girls. Based on the data, it can be explained that the number of children with autism spectrum disorder specifications is mostly experienced by boys. Zablotsky et al, (2019) in their research entitled "Prevalence and Trends of Developmental Disabilities among Children in the United States: 2009-2017" found that boys experience more developmental disorders than girls in almost all specifications of the disorder and resistance. This shows that boys have more potential for developmental disorders and barriers. Referring to the results above, the five children with autism spectrum disorder specifications are all boys, two boys with ADHD and two others have not been diagnosed, the rest are 3 girls with speech delay, Down syndrome and one child who has not been diagnosed.

During the Covid-19 pandemic, teachers can ask parents to send photos of their children's work or videos of their children's activities at home. It can be sent via e-mail or WhatsApp group. The results of developmental achievements related to children's life skills were obtained from documentation in the form of photos and videos sent by parents to teachers during learning from home. The teacher then makes an assessment through photos or videos of the child's activity process in life skills. The following describes the results of the I-Teach model implementation on children's life skills during their learning from home (Distance Learning) period.

Tabel 4. Tabulation of Life Skills Achievements for Children with Special Needs

\begin{tabular}{|c|c|c|c|c|c|c|c|c|c|c|c|c|c|c|c|}
\hline \multirow[t]{2}{*}{ Component } & & \multicolumn{12}{|c|}{ Score } & \multirow{2}{*}{ 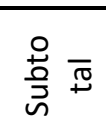 } & \multirow{2}{*}{$\begin{array}{l}\bar{\pi} \\
\stackrel{0}{0}\end{array}$} \\
\hline & & S1 & S2 & S3 & S4 & S5 & S6 & S7 & S8 & S9 & $\begin{array}{l}\text { S1 } \\
0\end{array}$ & S11 & $\begin{array}{l}\text { S1 } \\
2\end{array}$ & & \\
\hline Feeding & a.. & 4 & 2 & 3 & 4 & 3 & 2 & 2 & 3 & 4 & 4 & 2 & 4 & 37 & 131 \\
\hline \multirow[t]{3}{*}{ Self } & b.. & 4 & 2 & 3 & 4 & 2 & 2 & 4 & 3 & 4 & 4 & 2 & 4 & 38 & \\
\hline & c.. & 2 & 4 & 2 & 4 & 2 & 2 & 2 & 3 & 4 & 2 & 2 & 2 & 31 & \\
\hline & d.. & 2 & 2 & 2 & 4 & 2 & 2 & 4 & 1 & 2 & 1 & 1 & 2 & 25 & \\
\hline \multirow[t]{3}{*}{ Dressing } & a.. & 4 & 1 & 3 & 2 & 2 & 2 & 4 & 1 & 2 & 2 & 1 & 2 & 26 & 74 \\
\hline & b.. & 2 & 1 & 3 & 4 & 2 & 2 & 4 & 2 & 2 & 0 & 1 & 2 & 25 & \\
\hline & c.. & 2 & 2 & 3 & 4 & 2 & 2 & 2 & 1 & 2 & 0 & 1 & 2 & 23 & \\
\hline Personal & a.. & 4 & 2 & 3 & 4 & 3 & 2 & 2 & 3 & 4 & 2 & 2 & 2 & 33 & 109 \\
\hline \multirow[t]{3}{*}{ Hygiene } & b.. & 2 & 1 & 3 & 2 & 2 & 2 & 4 & 3 & 2 & 0 & 1 & 2 & 24 & \\
\hline & c.. & 4 & 1 & 2 & 2 & 1 & 2 & 3 & 3 & 2 & 4 & 0 & 4 & 28 & \\
\hline & d.. & 4 & 1 & 2 & 2 & 1 & 2 & 2 & 4 & 2 & 2 & 0 & 2 & 24 & \\
\hline Self- & a.. & 2 & 2 & 2 & 4 & 1 & 2 & 1 & 4 & 2 & 2 & 1 & 0 & 23 & 74 \\
\hline Awarene & b.. & 2 & 2 & 3 & 2 & 2 & 2 & 4 & 4 & 2 & 2 & 1 & 2 & 28 & \\
\hline $\mathbf{s}$ & c.. & 2 & 2 & 2 & 2 & 2 & 2 & 1 & 4 & 2 & 2 & 1 & 1 & 23 & \\
\hline \multirow[t]{2}{*}{ Safety } & a.. & 2 & 1 & 3 & 2 & 1 & 2 & 2 & 3 & 4 & 2 & 0 & 1 & 23 & 46 \\
\hline & b.. & 2 & 1 & 2 & 2 & 1 & 2 & 2 & 4 & 4 & 2 & 0 & 1 & 23 & \\
\hline Relating & a.. & 2 & 2 & 3 & 4 & 1 & 1 & 3 & 3 & 2 & 2 & 1 & 1 & 26 & 56 \\
\hline $\begin{array}{l}\text { Well with } \\
\text { Others }\end{array}$ & b.. & 2 & 2 & 3 & 4 & 1 & 2 & 4 & 4 & 2 & 2 & 2 & 2 & 30 & \\
\hline
\end{tabular}


Table Description:
Feeding Self
a. Able to eat and drink independently
b. Able to use eating and drinking utensils well
c. Able to tidy up their own eating and drinking utensils
d. Able to clean eating and drinking utensils by themselves
Dressing
a. Able to dress themselves with simple technology (zipper or button with various models and sizes)
b. Able to wear their own socks
c. Able to use automatic shoes and simple laces
Personal
Hygine
a. Able to clean themselves by washing their hands properly without help
b. Able to brush their teeth using toothpaste and toothbrush in the right order
c. Able to go to the restroom without assistance (to urinate)
d. Able to go to the restroom without assistance (to defecate)
Self-
a. Able to understand themselves
Awarenes
b. Able to control emotions
c. Calm themselves when facing an undesired situation
Safety
a. Have the sensitivity and ability to avoid dangers that are around them while studying
b. Have the sensitivity and ability to avoid the dangers around them while playing
Relating Well
a. Able to interact with peers
with Others
b. Able to interact with adults
c.

Based on the data above, the results of children's life skills can be described on the six indicators as illustrated in figure 1.

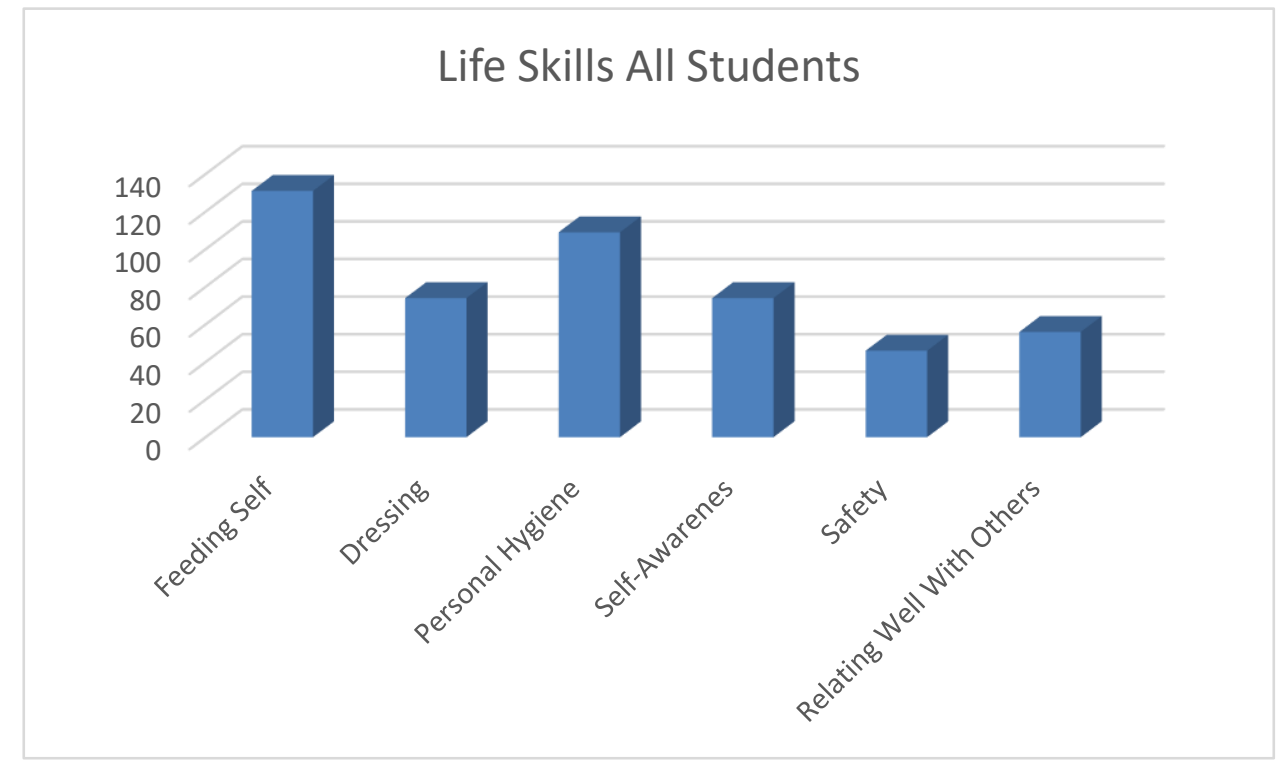

Figure 1. Life Skills Results of Children with Special Needs 
Based on the above figure, it is known that the component of life skills in the form of feeding self is the component that is most successfully mastered by the students, followed by personal hygiene, relating well with others, and safety. The following is the percentage of the overall achievement of life skills indicators for children with special needs described in table 5.

Table 5. Percentage of Achievement in Life Skills for All Students

\begin{tabular}{lcc}
\hline & Overall Students & \\
\hline \multicolumn{1}{c}{ Life Skills Components } & Total & Percentage \\
Feeding Self & 131 & $27 \%$ \\
Dressing & 74 & $15 \%$ \\
Personal Hygiene & 109 & $22 \%$ \\
Self-Awarenes & 74 & $15 \%$ \\
Safety & 46 & $9 \%$ \\
Relating Well with Others & 56 & $11 \%$ \\
\hline
\end{tabular}

The following describes the results related to the achievement of each indicator item in the life skills component given to children with special needs while studying from home.

a. The component of life skills in the form of feeding self is the component that is most successfully achieved by students, in Feeding Self there are four (4) indicators, namely:

Table 6. The Percentage of Feeding Self Indicator

\begin{tabular}{|c|c|c|c|}
\hline \multicolumn{4}{|c|}{ Feeding Self Component } \\
\hline & Indicator & Total & Percentage \\
\hline & Able to eat and drink independently & 37 & $28 \%$ \\
\hline & Able to use eating and drinking utensils well & 38 & $29 \%$ \\
\hline & Able to tidy up their own eating and drinking utensils & 31 & $24 \%$ \\
\hline & Able to clean eating and drinking utensils by themselves & 25 & $19 \%$ \\
\hline
\end{tabular}

Based on the table above, it can be concluded that the indicator of being able to use eating and drinking utensils well is an indicator that has been successfully carried out by children, while the indicator of being able to clean eating and drinking utensils by themselves is the most difficult indicator for children or it could be because they had not been able to do it.

b. The life skills component in the form of dressing has a percentage of being successfully carried out by all children by $15 \%$, where there are three (3) indicators, namely:

Tabel 7. The Percentage of Dressing Indicator

\begin{tabular}{llcc}
\hline \multicolumn{1}{c}{ Indicator } & Total & Percentage \\
\hline & & $35 \%$ \\
a. Able to dress themselves with simple technology & 26 & $34 \%$ \\
(zipper or button with various models and sizes) & 25 & $31 \%$ \\
b. Able to wear their own socks & 23 & \\
c. Able to use automatic shoes and simple laces & & \\
\hline
\end{tabular}


Based on the data above, it can be explained that the indicator of being able to dress themselves with simple technology (zippers and buttons with various models and sizes) is the indicator that is mostly mastered by children, while the indicator of being able to use automatic shoes and simple laces is the most difficult indicator for children to do, especially lace-up shoes.

c. The component of life skills in the form of personal hygiene has a percentage of $22 \%$, of which there are four (4) indicators, namely:

Table 8. The Percentage of Personal Hygine Indicator

\begin{tabular}{lcc}
\hline \multicolumn{1}{c}{ Personal Hygiene Component } & \\
\hline \multicolumn{1}{c}{ Indicator } & Total & Percentage \\
a. Able to clean themselves by washing their hands properly & 33 & $30 \%$ \\
without help & & $22 \%$ \\
b. Able to brush their teeth using toothpaste and toothbrush in the & 24 & $26 \%$ \\
right order & 28 & $22 \%$ \\
c. Able to go to the restroom without assistance (to urinate) & 24 & \\
d. Able to go to the restroom without assistance (to defecate) & & \\
\hline
\end{tabular}

Based on the data above, it is known that in the personal hygiene component, the indicator of being able to clean themselves by washing their hands properly without help is an indicator that has been most mastered by all children. Other indicators such as brushing teeth, urinating and defecating are still difficult for children with special needs, so they need help, direction, and repetition at every step in these skills.

The three life skills indicators described above (feeding self, dressing, and personal hygiene were developed not only as children's training on the independence aspect, but also the physical motor aspect. This was emphasized by Budury et al. (2020) that the physical motor aspect can be developed through self-care skills activities, buttoning, tying ropes and others, this activity also develops confidence in children by being given opportunities, time, and practice. Personal hygiene is a human need. Personal hygiene is a practice that is carried out by someone by nursing, maintaining, or caring for personal hygiene, such as keeping the hair, eyes, ears, nose, mouth, nails, private parts and appearance clean. In children with special needs some of them experience delays and obstacles in all aspects of development, so that children have difficulty taking care of themselves (Bergström et al., 2013; Ge et al, 20 19). Personal hygiene in children is part of the maintenance effort for themselves, which includes sanitation and health to get physical fitness and disease prevention that must be introduced and taught from an early age (Hidayati et al., 2019, p.391).

d. The life skill component in the form of self-awareness has a percentage of $15 \%$, of which there are three (3) indicators, namely:

Table 9. The Percentage of Self-Awarenes Indicator

\begin{tabular}{llcc}
\hline \multicolumn{3}{c}{ Self-Awarenes Component } \\
\hline \multicolumn{1}{c}{ Indicator } & Total & Percentage \\
a. Able to understand themselves & 23 & $31 \%$ \\
b. Able to control emotions & 28 & $38 \%$ \\
c. Calm themselves when facing an undesired & 23 & $31 \%$ \\
& & \\
\hline
\end{tabular}


Based on the data above, the life skills component in the form of self-awareness has indicators of being able to control emotions which are most successfully carried out by students, while the indicators that are the most difficult for children to do well are being able to understand themselves and calm themselves down when situations are not desired. Children who are aware, understand, have selfawareness, and approve of themselves are more likely to have positive perceptions of themselves, and will be able to regulate and adapt to their environment (Wehmeyer, Argan, \& Hughes, 2000). For children with special needs, they must learn to develop their competence, master skills to understand their strengths and limitations, as well as have an awareness of their own abilities.

e. The life skills component in the form of safety has a percentage of $9 \%$, of which there are two (2) indicators, namely:

Table 10. The Percentage of Safety Indicator

\begin{tabular}{|c|c|c|c|}
\hline \multicolumn{4}{|c|}{ Safety Component } \\
\hline & Indicator & Total & Percentage \\
\hline a. & $\begin{array}{l}\text { Have the sensitivity and ability to avoid dangers } \\
\text { that are around them while studying }\end{array}$ & 23 & $50 \%$ \\
\hline & $\begin{array}{l}\text { Have the sensitivity and ability to avoid the } \\
\text { dangers around them while playing }\end{array}$ & 23 & $50 \%$ \\
\hline
\end{tabular}

Based on the data above, it is known that the life skills component in the form of safety has two indicators that can be done well by children. Based on the results described above and interviews with teachers and parents, on average, children are still not aware of the dangers around them, children's sensitivity has not emerged and most of them are still busy with their own world and do a lot of undirected activities. This causes children not to have awareness of their existence in their environment. Safety can be built from the environment around children. When they play, the environment has been arranged safely and comfortably for children. This is to anticipate so that children avoid danger or insecurity that threatens themselves (Laverty \& Reay, 2014).

f. The life skills component in the form of relating well with others has a percentage of $11 \%$, of which there are two (2) indicators, namely:

Table 11. The Percentage of Relating Well with Others Indicator

\begin{tabular}{llll}
\hline \multicolumn{4}{c}{ Relating Well with Others Component } \\
\hline \multicolumn{1}{c}{ Indicator } & Total & Percentage \\
a. Able to interact with peers & 26 & $46 \%$ \\
b. Able to interact with adults & 30 & $54 \%$ \\
\hline
\end{tabular}

Based on the data above, it is known that the component of life skills in the form of relating well with others has an indicator of being able to interact with adults which is an indicator that has been mastered the most by all students, while the indicator of being able to interact with peers was not performed well by the children. This is corroborated from the results of interviews that adults understand more about the condition of children and how they feel more protected by adults than their peers. Children can have the ability to interact with peers and adults. This is one of the developmental achievements that must be fulfilled in their developmental tasks. This is in accordance with the achievement target of IDEA'S Early Childhood Programs: 2014-15 for children with special needs, namely children who have social relationships with peers and have good relations with adults (ECTA Center, 2016, p.1). 


\section{Discussion}

This pandemic period has also changed the life skills learning process which was originally carried out face-to-face between children and teachers, so it is necessary to involve parents who must be teachers for their children while learning from home. However, this pandemic has also created opportunities for teachers to involve parents in education and teaching. Teachers and parents work together, communicate, and create various learning solutions for children with special needs that are carried out online (Willis \& Exley, 2020).

The implementation of the I-Teach model in PAUD institutions in the second year and during this pandemic is not an easy task for teachers who teach children special needs. In the face-to-face learning process, teachers often experience various obstacles in providing interventions to maximize growth and development, as well as optimize the potential possessed by children. This is exacerbated by the outbreak of the corona virus which has been threatening regions in Indonesia for more than a year, practically the world of face-to-face education has stopped until now. This also has an impact on inclusive early childhood education institutions, by accepting children with special needs in them who have not yet fully provided optimal education services in schools.

Learning programs and development activities for children with special needs that should be provided at school, are fully carried out by parents or family at home during the pandemic. This means that teachers design activities that parents can do and train their children while at home. The activity which is one of the programs of the I-Teach model is the life skills program. This pandemic period provides a great opportunity for children to practice life skills while they study from home. Life skills can be given and trained to children with special needs through various activities, including in the form of playing activities. It is important to be able to distinguish play-based learning, and learning by playing, where fun playing activities are the goal (Pyle \& Daniels, 2017).

Some of the life skills activities that have been described above show that there are several indicators of life skills that have been mastered but some items in them still require assistance and help from parents to practice. These skills can be packaged in the form of pretend play activities or dramatic play, so that it seems as if the child is really doing these activities with the help of games. For example, for eating and drinking skills, in addition to children being able to perform these activities for real, they can also be invited to play "go to a restaurant". This activity not only trains children to use cutlery, but also the ability to interact with peers or other adults. For personal hygiene skills in urinating and defecating, basically they need repeated practice from the activities they do every day. In addition, teaching children about self-awareness is also an important part so that children understand themselves, can control emotions, if they know that children with special needs have unstable emotions and are more emotional than children in general.

Training children in life skills is the same as developing and training children's physical, motor, language, and social emotional aspects. Life skills skills are designed to give children the opportunity to practice life skills in their daily activities, so that even if the child does not receive assistance from the teacher, parents can still provide the best possible intervention. However, the program did not run as well as expected. There are supporting and inhibiting factors during the implementation process, including: the supporting factors in the implementation of the I-Teach model for children with special needs are parental and family support at home. Parents have a role as the first and main teacher while the child is studying at home, the active communication between parents and teachers in implementing the given program is an important part of the success of the program. In addition, the involvement and support of other family members is also a motivation for children to be able to carry out their skill 
activities (Nurjanah \& Diana, 2020). Consistency in carrying out each activity on each skill is also a major element in the implementation of this life skills program, so that through consistent practice and repetition, children will be more skilled in mastering each expected life skill item. The same thing has also been described by Machmudah et al. (2020) in his research that parental involvement is very necessary in achieving children's life skills at home, in other words that this pandemic has made the role of parents in education for their children more strategic. In addition, parents find certain ways and strategies that are initially a series of "trial and error" in every life skills activity for children. This is also influenced by various factors from parents such as educational background, socioeconomic, cultural differences in carrying out their children's education at home (Kean, 2005; Dewanggi et al., 2012; Lehrl et al., 2020). Kluczniok \& Roßbach (2014) also confirmed the results of their research regarding the effect of family support on children's development, where there is a positive relationship between teachers and parents, there is interaction and cooperation between children and parents, in addition the teacher helps parents to provide stimulation strategies for children when at home. The provision of facilities and infrastructure in accordance with the ability of parents to support various life skills activities for children is also a supporting factor by providing opportunities for children to practice with media or tools provided during learning from home.

The inhibiting factors in implementing the I-Teach model on the life skills of children with special needs are parents and families at home. During the pandemic, children do a lot of activities and learning at home, but not all children get the full attention of their parents or family while at home. The busyness of parents in meeting family needs is an obstacle in implementing life skills activity programs for children at home. Other family members also don't want to be "bothered" with various things that should allow children to be trained in their independence and responsibility, instead they provide services that are "pampering" so that children do not throw a "tantrum" when they cannot or fail to do something.

The lack of support for facilities and infrastructure to train children's various life skills is also an inhibiting factor. This makes children getting less opportunity to practice with media or supporting tools that should help when children learn from home. In addition, there are no other supporting components, such as psychologists, doctors or therapy that can help monitor children's development consistently and provide interventions that are partially lost in the absence of face-to-face meetings with teachers at school (Bock \& Borders, 2015; Coughlin, 2017; Padmadewi et al. al., 2020). If children lack the support of other adults (such as teachers or other support personnel in the early stages of life, they are basically at a disadvantage (Nel et al., 2016, p.3). Professional involvement and support have a very positive impact. on the development of children with special needs, because of the role of teachers, parents become one of the strengthening interventions in providing services and strengthening children's life skills while learning from home. Teachers can use empathy, compassion, and provide understanding to help empower families of children with special needs (Moriwaka, 2012; Turnbull \& Turnbull, 2015), helps instruct parents to teach skills in providing life skills interventions for children while at home such as sending a video showing the steps on each life skill indicator to be trained. This will reduce the level of stress experienced by many parents assisting their children at home (Ott, 2015, p3). It is undeniable that many parents who have children with special needs have difficulty in accompanying and teaching their children in both simple and more complex skills.

In the implementation of the I-Teach model related to the life skills program for children with special needs in this study besides teachers, parents have an important role in child development, positive and negative reactions from parents play a key role in their development. Thus, parents of these special children (children with special needs) must raise their children optimistically so that their development 
can be optimal (Pancawati et al., 2019; Karaca, 2020). Parents play a significant role in mentoring their children so that they will have the life skills they need in the future.

\section{Conclusion}

The implementation of the inclusive teaching (I-Teach) model in the life skills activity program while studying from home during the COVID-19 pandemic has a positive impact on children with special needs. The life skills program which is described in the six life skills indicators which are taught to children with special needs while learning from home has generally been carried out, but some items in each indicator are skillfully mastered and some have not been mastered. Skills such as self-feeding (eating and drinking alone with cutlery), dressing (buttoning clothes, wearing socks), personal hygiene (washing hands) have been mastered well by children. The skills of self-awareness, safety, and relating well with others still require intensive reinforcement and guidance by teachers and parents. Various obstacles and challenges for parents in assisting and training their children's life skills while at home are factors that both support and hinder the smooth implementation of the program. This is a motivation for teachers to be able to continue to aid and actively communicate to parents by providing simple steps through learning videos that can be taught by parents, combined with face-to-face meetings which are still very limited. There is a scheduled home visit for teachers and students take turns coming to school by following a strict health protocol. There are some skills that have not been mastered by children, it is hoped that their guidance and assistance can be maximized while at home, both with parents, family members, or other adults. Although parents can be both the supporting and inhibiting factors in the achievement of children's life skills at home, they still play a big role in providing support and facilities to achieve these skills. The role of the teacher in providing positive assistance and support to parents is an important part, so that parents have the confidence and motivation to accompany their children while at home.

\section{Recommendation}

This research provides recommendations to all early childhood education institutions to be able to help implement the inclusive teaching (I-Teach) model so that every child with special needs has the same opportunity to grow and develop optimally. Life skills education, which is one of the main programs in the I-Teach model, can be a mandatory and planned program to be given to children so that they have the skills and readiness to face the next level in life. It is no less important that these life skills are given so that they are also able to adapt and adjust to the environment and the world of work in the future.

\section{Acknowledgement}

I would like to express my gratitude to all early childhood educators who have given their dedication in the world of education, especially the teachers who teach children with special needs for their love and patience in dealing with special children. The involvement and role of teachers in this research is an important part in implementing inclusive learning at the level of early childhood education.

\section{Funding}

This research was funded by the Directorate of Research and Community Service, Deputy of Research and Development Support, Ministry of Research, Technology, and Higher Education/ National Agency for Research and Innovation through the 2021 Doctoral Dissertation Research scheme. 
Diana, D., Sunardi, S., Gunarhadi, G \& Yusufi, M. (2021). Reviewing the life skills activity program for children with special needs during the COVID-19 pandemic. Cypriot Journal of Educational Science. 16(6), 3240-3254. https://doi.org/10.18844/cjes.v16i6.6543

\section{References}

Assingkily, Muhammad, S., \& Miswar. 2020. The urgency of moral education for elementary age children (study of the Covid 19 emergency era). Jurnal of PGMI STIT Al-Ittihadiyah Labuhanbatu Utara,1(1). E-ISSN : 2721056.

\section{http://jurnal.stit-al-ittihadiyahlabura.ac.id/index.php/bunayya/article/view/62/49}

Bergström H., Hagströmer M., Hagberg J., Elinder L. S. (2013). A multi-component universal intervention to improve diet and physical activity among adults with intellectual disabilities in community residences: A cluster randomised controlled trial. Res Dev Disabil, 34(11):3847-57. doi: 10.1016/j.ridd.2013.07.019.

Bock, S. J., \& Borders, C. (2015), Roles of related professionals in special education, interdisciplinary connections to special education: Important aspects to consider. Advances in Special Education, 30(A), Bingley: Emerald Group Publishing Limited, pp. 119-129. https://doi.org/10.1108/S0270-40132015000030A005.

Budury, S., Khamida, K., Nurjanah, S., \& Jalaluddin, T. J. (2020). Improving the fine motor skills with embroidery among children with an intellectual disability. Jurnal Ners, Special Issues, 72-74. doi: http://dx.doi.org/10.20473/in.v15i2.19011.

Coughlin, S. L. (2017). Collaborative practices among professionals in special education workplaces. Honors Theses and Capstones, 331. Spring: University of New Hampshire.

https://scholars.unh.edu/honors/331

Kean, D. P. E. (2005). The influence of parent education and family income on child achievement: The indirect role of parental expectations and the home environment. Journal of Family Psychology, 19(2), 294304. https://doi.org/10.1037/0893-3200.19.2.294.

Dewanggi, M., Hastuti, D., \& Hernawati, N. (2012). Parental care and independence of children aged 3-5 years based on gender in Urug traditional village. Journal of Family and Consumer Science, 5(1), 19-28.

Diana, Sunardi, Gunarhadi, \& Munawir, Y. (2020). The development of I-Teach model to improve early childhood teacher's professionalism. Cypriot Journal of Educational Science. 15(6), 1614-1628. https://doi.org/10.18844/cjes.v15i6.5321.

Early Childhood Technical Asisstance Center. (2016). Outcome for children served through IDEA'S early childhood program: 2014-15. Chapel Hill: ECTA Center.

Gamutu, J., C., \& Kathuri, W., N. (2018). An exploration of life skills programme on pre-school children in Embu West, Kenya. Journal of Curriculum and Teaching, 7(1), 1-6.

Ge, T., Zhang, Q., Lu, J., Chen, G., Sun, M., \& Li, X.(2019). Association between education and health outcomes among adults with disabilities: Evidence from Shanghai, China. PeerJ 7:e6382 https://doi.org/10.7717/peerj.6382.

Hidayati, T., Akrom, Nurasa, I., \& Erviana. (2019). Health education improve behavior and self-efficacy on personal hygiene among children with intellectual disability. International Journal of Public Health Science (IJPHS,8(4,) pp. 391-399. ISSN: 2252-8806, DOI: 10.11591/ijphs.v8i4.20370.

Jamaluddin, Dindin dkk. (2020). Online learning during the COVID-19 pandemic for prospective teachers: obstacles, solutions, and projections. Bandung: Sunan Gunung Djati Islamic State University.

Karaca, M. A., Efilti, E. (2020). The communication between parents with special needs children and their typically developing children in TURKEY. European Journal of Special Education Research, 6(2), 86-109. DOI: 10.46827/ejse. v6i2.3253

Ministry of Education and Culture of the Republic of Indonesia. (2020). Assessment of child development during learning from home. Jakarta: Directorate of Early Childhood Education, Ministry of Foreign Affairs. 
Kluczniok, K., \& Roßbach, H.-G. (2014). Conceptions of educational quality for kindergartens. Zeitschrift für Erziehungswissenschaft, 17(S6), 145-158. doi:10.1007/s11618-014-0578-2

Laverty, B., Reay, B. (2014). Health and safety in early years and childcare: Contextualising health and safety legislation within the early year foundation stage. London: The National Children's Bereau.

Lehrl, S., Evangelou, M., \& Sammons, P. (2020). The home learning environment and its role in shaping children's educational development. School Effectiveness and School Improvement, 31(1), 1-6. https://doi.org/10.1080/09243453.2020.1693487

Machmudah, Chusniyah, T., Prastuti, E, Kamariyah, N., \& Shodiq, M. (2020). The influence of parental engagement training on theincreased life skills of elementary children in the beginning class during the covid pandemic 19. Proceedings of the International Conference on Ummah Digital Innovation, Humanities And Economy (ICU: DIHEC) 2020. http://doi.org/1030874/ksshr.

Moriwaka, M. (2012). Empowering parents and educators to develop home-school partnerships in K-12 special education (Doctoral dissertation, Walden University). Retrieved March 22, 2015, from http://gateway.proquest.com/openurl?url ver=Z39.88-

2004\&rft val fmt=info:ofi/fmt:kev:mtx:dissertation\&res dat=xri:pqm\&rft dat=xri:pqdiss:3546150.

Nel. N. M., Tlale. L. D. N., Engelbrecht, P., \& Nel, M. (2016). Teachers' perception of education support structure in the implementation of inclusive education in South Africa. Koers, 81(3), 1-14. https://dx.doi.org/10.1908/koers.81.3.2249.

Nurjanah, D.M., \& Diana. (2020). The Parents Involvement In Implementation Of Early Childhood Inclusive Education. The 4th International Conference on Learning Innovation and Quality Education Surakarta Indonesia, Association for Computing Machinery. ACM ISBN 978-1-4503-7572-6/20/09

\section{https://dl.acm.org/doi/10.1145/3452144.3453742}

Ott, L. (2015). families with special needs children and stress: research review. BU Journal of Graduate Studies in Education, 7( 2). https://files.eric.ed.gov/fulltext/EJ1230692.pdf

Padillo, G. G., Espina, R. C., Capuno, R. G., Manguilimotan, R. P., Calasang, V. O., \& Bellete, J. B. (2021). Functional skills for learners with special educational needs amidst the COVID-19 pandemic. Cypriot Journal of Educational Science. 16(4), 1893-1916. https://doi.org/10.18844/cjes.v16i4.6057

Padmadewi, N. Y., Artini, L. P., Suarnajaya, W. (2020). Training for handling children with special needs for teachers in primary schools. Proceeding of Senadimas Undiksha 2020, 20-34. ISBN 978-623-7482-47-5.

Pancawati, A., Pitaloka, A. D., Sasqia, D. A. (2019). The role of parents in fulfilling learning for children with mental disorders. Journal of Social Science Education, 28(2), 115-124. http://dx.doi.org/10.17509/jpis.v28i2.14151.

Pyle, A., \& Daniels, E. (2017). A continuum of paly-based learning: the role of the teacher in play-based pedagogy and the fear of hijacking play. Physcology-Early Education and Development, 28, 274-289.

The University of the State of New York. (2003). Preschool special education: Learning outcomes and indicators for kindergarten participant. The State Education Department: Office of Vocational and Educational Services for Individuals with Disabilities.

Turnbull, A., \& Turnbull, R. (2015). Looking backward and framing the future for parents' aspirations for their children with disabilities. Remedial and Special Education, 36(1), 50-56. doi:10.1177/0741932514553124

Wajdi, \& Nizarudin, M. B. 2020. Assistance in redesigning learning during the COVID-19 pandemic for educators at Islamic boarding schools in East Java. Journal of Community Service. 4(1).

Wijoyo, Hadion \& Irjus Indrawan. 2020. Learning model to welcome the new normal era at Early Childhood Education institutions in Riau. Jurnal of Elementary School Education, Faculty of Education, Medan State University,4(3). 
Diana, D., Sunardi, S., Gunarhadi, G \& Yusufi, M. (2021). Reviewing the life skills activity program for children with special needs during the COVID-19 pandemic. Cypriot Journal of Educational Science. 16(6), 3240-3254. https://doi.org/10.18844/cjes.v16i6.6543

Wehmeyer, M. L., Agran, M., \& Hughes, C. (2000). A national survey of teacher's promotion of self-determination and student-directed learning. The Journal of Special Education, 34(2), 58-68.

Willis, L. D., \& Exley, B. (2020). Engaging parents in their child's learning and wellbeing: Change, continuity, and COVID-19 [Issues paper]. https://www.isq.qld.edu.au/publicationsresources/posts/engaging-parents-intheirchild-s-learning-and-wellbeing/

Zablotsky, B., Black, L. I., Maenner, M. J., Schieve, L. A., Danielson, M. L., Bitsko, R. H., Blumberg, S. J., Kogan, M. D. C. A. (2019). Prevalence and trends of developmental disabilities among children in the United States: 2009-2017. PEDIATRICS,144(4), 1-13. 